\title{
The high frequency of juvenile Huntington's chorea in South Africa
}

\author{
M R HAYDEN*, J M MACGREGOR $\dagger$, D S SAFFER+, AND P H BEIGHTON* \\ From *the Department of Human Genetics, University of Cape Town, Medical School, Observatory 7925; \\ $\dagger$ Department of Neurology, Groote Schuur Hospital, Observatory 7925; and $\ddagger$ Department of Neurology \\ and Neurosurgery, Baragwanath Hospital and University of the Witwatersrand, Johannesburg, South Africa
}

SUMMARY During a national investigation concerning all patients with Huntington's chorea in South Africa, 17 affected children, comprising $7 \cdot 7 \%$ of the patients in the survey, were identified. Although the frequency of juvenile Huntington's chorea in the white community was equal to that reported from around the world, the frequency was much higher in the population of mixed ancestry. It is possible that this unique situation is related to the genetic constitution of this latter group.

Lyon ${ }^{1}$ was the first to record a patient with juvenile Huntington's chorea when he described two children (sibs) in whom well defined chorea had existed for many years. Huntington in his classic paper of $1872^{2}$ failed to recognise this precocious form of the disease. In fact, he stated emphatically that a peculiarity of the disorder is that it "manifests itself as a grave disease only in adult life". Since that time approximately 150 separate papers concerning juvenile Huntington's chorea have been published. ${ }^{3}$

In spite of this large bibliography, confusion still exists with regard to the nosology of Huntington's chorea. In this article the term 'juvenile Huntington's chorea' pertains to affected persons with definite signs and symptoms which present before the age of 20. It encompasses both the 'childhood' (with onset before 10) and the 'adolescent' forms of the disease (earliest clinical features appearing in the second decade).

Saffer et $a l^{4}$ first reported the presence of juvenile Huntington's chorea in four sibs of a family of mixed descent. During a national survey in which every available affected person with Huntington's chorea in South Africa was investigated, it was found that there was a relatively high proportion of patients with onset of the disease before the age of 20 , especially in the population of mixed ancestry. The purpose of this paper is to report this unusual situation and to discuss possible reasons for the high frequency of juvenile Huntington's chorea in this group.

Received for publication 24 April 1981

\section{Methods}

Affected subjects were initially ascertained through the records of the Department of Human Genetics, University of Cape Town, and subsequently through the admission and discharge records of Groote Schuur Hospital, Cape Town. Letters requesting information on persons with Huntington's chorea and their families were later sent to all psychiatrists and neurologists and selected general practitioners and physicians known to have an interest in the condition or to have come into contact with affected subjects. The location of the major psychiatric and mental health centres in this country is shown in the figure. Letters were sent to superintendents of all these hospitals, as well as to other smaller psychiatric hospitals and provincial hospitals with departments of psychiatry and neurology.

After replies to these enquiries had been received, a map of South Africa with the location of affected subjects was constructed. Permission was then requested from supervising doctors for one of us (MRH) to visit and examine families in different parts of the country.

A complete general and neurological examination was made of each patient. Details concerning the age of onset were carefully noted. For this investigation, the age of onset of the disorder was defined as "the first time at which any signs or symptoms appeared which were either neurological or psychiatric and represented any change from the normal state". Pedigrees were assembled for all families. Full details of the methodology are reported elsewhere. ${ }^{56}$ 


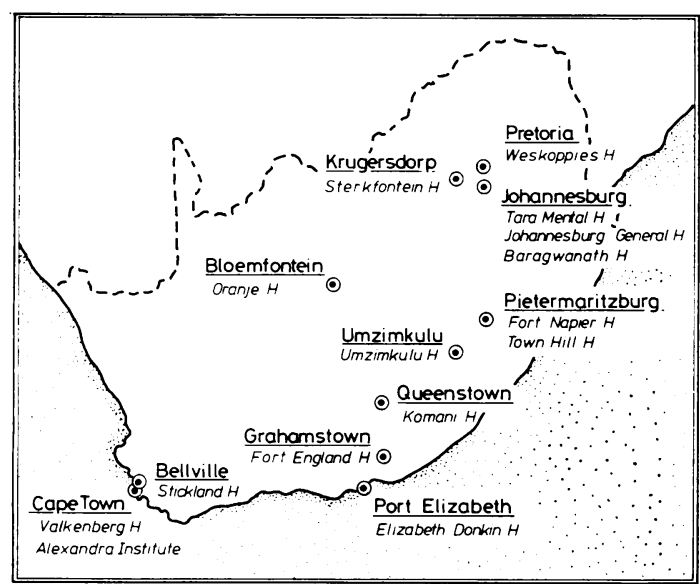

FIGURE The location of the major mental health hospitals in South Africa.

\section{Results}

Of the 480 patients who were investigated, adequate details concerning age of onset were available in 219 persons, comprising 147 whites and 72 of mixed ancestry. Of the total, 17 had onset before the age of 20 , representing $7.7 \%$ of all patients in the survey, six patients being in the white community and 11 in the group of mixed ancestry.

The number of juvenile patients expressed as a percentage of the total South African survey population is shown in table 1 . A total of $15.7 \%$ of the total survey population in the group of mixed ancestry had onset of the disease before the age of 20 , as opposed to $4 \%$ in the white group. These results are compared with the findings of previous investigations in the same table.

TABLE 1 Number of juvenile patients expressed as a percentage of the total survey population

\begin{tabular}{|c|c|c|c|c|c|c|c|}
\hline \multirow{3}{*}{ Reference } & \multicolumn{7}{|c|}{ Age of onset } \\
\hline & \multicolumn{2}{|c|}{$\begin{array}{l}\text { Childhood } \\
0-9\end{array}$} & \multicolumn{2}{|c|}{$\begin{array}{l}\text { Adolescent } \\
10-19\end{array}$} & \multicolumn{2}{|c|}{ Total } & \multirow[t]{2}{*}{ Country } \\
\hline & $\overline{N o}$ & $\%$ & No & $\%$ & $\overline{N o}$ & $\%$ & \\
\hline 7 & 3 & $2 \cdot 2$ & 2 & $1 \cdot 4$ & 5 & $3 \cdot 6$ & USA \\
\hline 8 & 一 & 一 & 1 & $4 \cdot 7$ & 1 & $4 \cdot 7$ & Wales \\
\hline 9 & 9 & $2 \cdot 0$ & 22 & $4 \cdot 9$ & 31 & $6 \cdot 9$ & Germany \\
\hline 10 & - & - & 12 & $5 \cdot 9$ & 12 & $5 \cdot 9$ & USA \\
\hline 11 & 4 & $1 \cdot 9$ & 11 & $5 \cdot 3$ & 15 & $7 \cdot 2$ & Australia \\
\hline 12 & 2 & 0.9 & 9 & $3 \cdot 9$ & 11 & $4 \cdot 8$ & Scotland \\
\hline 13 & 一 & 一 & 2 & $2 \cdot 9$ & 2 & $2 \cdot 9$ & England \\
\hline 14 & 4 & $3 \cdot 5$ & 7 & $6 \cdot 1$ & 11 & $9 \cdot 6$ & England \\
\hline 15 & & & & & 13 & $8 \cdot 0$ & Sweden \\
\hline 16 & 1 & $0 \cdot 3$ & 2 & 0.7 & 3 & $1 \cdot 0$ & England \\
\hline Current study & 6 & $2 \cdot 7$ & 11 & $5 \cdot 0$ & 17 & $7 \cdot 7$ & South Africa \\
\hline Whites & 3 & $2 \cdot 0$ & 3 & $2 \cdot 0$ & 6 & $4 \cdot 0$ & \\
\hline Mixed ancestry & 3 & $4 \cdot 3$ & 8 & $11 \cdot 4$ & 11 & $15 \cdot 7$ & \\
\hline
\end{tabular}

TABLE 2 Rate of Huntington's chorea $\times 10^{-5}$ in different populations of South Africa

\begin{tabular}{lccccc}
\hline Group & Age & $\begin{array}{l}\text { No of } \\
\text { patients }\end{array}$ & $\begin{array}{l}\text { O-20 yr } \\
\text { population }\end{array}$ & $\begin{array}{l}\text { Total } \\
\text { population }\end{array}$ & $\begin{array}{l}\text { Rate } \\
(\times 10-5)\end{array}$ \\
\hline $\begin{array}{l}\text { Whites } \\
\text { Mixed } \\
\text { ancestry }\end{array}$ & $0-20$ & 6 & 1599513 & 4050079 & 0.37 \\
\hline
\end{tabular}

The gene was transmitted $3 \cdot 2$ times more commonly by the father than the mother to affected juveniles in this country (that is, 13 fathers and four mothers of the 17 juvenile patients). The paternal line of descent was more common in the population of mixed ancestry than in the white group.

In order to correct for any possible bias due to different population structure the absolute rate $\left(\times 10^{-5}\right)$ of juvenile Huntington's chorea in the different populations was determined. The results of this calculation are shown in table 2 .

\section{Discussion}

The proportion of juvenile patients in different series varies from $1 \%{ }^{16}$ to $9.6 \%{ }^{14}$ of the affected population under study.

One of the major factors to be considered for these varied results is the different methods and criteria used for determination of the age of onset. Numerous studies, ${ }^{72-14}$ although stating mean ages when the disease began, do not adequately define their criteria for what constitutes onset of the disease. Reed et al ${ }^{10}$ consider the beginning of the disease to be the time of the appearance of chorea. On the other hand Panse, ${ }^{9}$ Brothers, ${ }^{11}$ Mattsson, ${ }^{15}$ and Stevens ${ }^{16}$ report age of onset to be that age at which the first symptoms occur, be they neurological (usually chorea) or psychiatric (including change in personality, irritability, moodiness, any signs of a decrease in intellectual functioning, and any psychotic behaviour). The different criteria used in these studies may account in part for the variation in the published results.

The percentage of $7 \cdot 7$ for juvenile patients in the South African study lies between the reported figures. However, separation of the results according to the frequency of juvenile Huntington's chorea in the different ethnic groups in South Africa reveals that while the proportion in the white group is $4 \%$, the corresponding figure for this form of the disorde1 in the population of mixed ancestry is $15.7 \%$. This latter figure is higher than any previously reported. There was a preponderance of paternal descent in the juvenile group, 13 persons inheriting the abnormal gene from their father, while only four persons had 
affected mothers. It is also relevant that no affected subject with juvenile Huntington's chorea was found in the African Negro population of approximately 19 million, where the disease is known to be exceedingly rare. There have only been three reports of the disease in this population group. ${ }^{41718}$

Numerous factors may be suggested to account for these findings. It is unlikely that these reflect a bias in the ascertainment of data, as similar methods were applied to all population groups with divergent results. It is difficult to postulate an environment mechanism for the observed results. However, Brackenridge $^{19}$ has shown a statistically significant decrease in age of onset as environmental temperature rises, but if climate were a factor the white group would also be expected to have an unusually high proportion of juvenile patients, and this does not occur. Furthermore, four of the 11 persons of mixed ancestry with Huntington's chorea come from the Transvaal, where the climate is different to that in the Cape, where the remaining seven patients reside.

Genetic factors may also be invoked to account for the ethnic differences in the distribution of juvenile patients and in these terms it is relevant to consider the origins of the different population groups of South Africa. The whites are predominantly of north-western European origin and it is therefore not unexpected that their frequency of juvenile Huntington's chorea is similar to that found in those European countries.

The population of mixed ancestry has, however, a unique genetic constitution, originally resulting from intermingling between whites, Khoisan (Bushmen and Hottentots), and Malaysian slaves in the 17th and 18 th centuries. The white immigration to the Cape during the earliest years of the settlement was very largely male ${ }^{20}$ and as a result adult females were constantly outnumbered. Many of those males who failed to find wives in their own ethnic group entered into unions with Khoisan or Malaysian women.

The gene for Huntington's chorea was probably introduced to South Africa over 300 years ago by one of the Dutch settlers, who arrived in this country in $1660 .^{5}$ There is on record a large affected family of mixed ancestry bearing the same uncommon name as one of the largest affected white kindreds who have previously been traced back to the earliest Dutch immigrants. Therefore, it is very likely that the gene for Huntington's chorea was introduced to this population group by males of European origin in the 17 th century. Since the father is the transmitter of the gene to affected juveniles three to four times more commonly than the mother, it could be suggested that there might be some link between the higher frequency of juvenile patients in the population of mixed ancestry and the predominant white male contribution to their origins. However, there are no precedents for this phenomenon in Mendelian genetics and this hypothesis is extremely speculative.

Another possible reason for the high proportion of juvenile patients in the population of mixed ancestry is that it is a reflection of their inherent genetic constitution, whereby their genome interacts with the gene for Huntington's chorea, modifying the phenotypic expression of the disease (epistasis) with resultant earlier age of onset. There is no way to test this hypothesis but, in the absence of any known environmental agents, it is most likely that genetic factors are important in the pathogenesis of this situation.

The prevalence of Huntington's chorea in the total white population and the population of mixed ancestry is essentially similar. ${ }^{6}$ The community of mixed ancestry as a whole has a large proportion of their population below the age of 20 and it could be argued that a higher absolute number of persons with juvenile Huntington's chorea would be present in this group. Correction for the shift in their population structure shows that the frequency of juvenile Huntington's chorea is still 2.4 times greater than that of the white group.

At present the disproportionately high frequency of juvenile Huntington's chorea in the population of mixed ancestry of South Africa remains a statistical finding for which there is no adequate biological explanation.

We are most grateful to Professor R Goodman of Tel Hashomer, Israel and $\mathrm{Dr} \mathbf{D} \mathbf{L}$ Stevens of England for their useful comments, and to Mrs G Shapley for typing the manuscript. The project was supported by grants from the Mauerberger Foundation Fund, the University of Cape Town Staff Research Fund, and the South African Medical Research Council.

\section{References}

1 Lyon IW. Chronic hereditary chorea. Am Med Times N $1863 ; 7: 289-90$.

2 Huntington G. On chorea. Medical and Surgical Reporter 1872;26:317-21.

3 Bruyn GW, Baro F, Myrianthopoulos NC. In: The centennial bibliography of Huntington's chorea (18721972). Leuven: Leuven University Press and Martinus Nijhoff, 1974;1-245.

4 Saffer DS, Nathan DC, Kahle PA, Steingo B. Huntington's disease in a coloured family. $S$ Afr Med $J \stackrel{\bigcirc}{\square}$ $1974 ; 48: 2399-402$. 
5 Hayden MR, Hopkins HC, Macrae M, Beighton PH. The origins of Huntington's chorea in the Afrikaner population of South Africa. $S$ Afr Med J 1980:58:197-200.

6 Hayden MR, MacGregor JM, Beighton P. The prevalence of Huntington's chorea in South Africa. $S$ Afr Med J 1980;58:193-6.

7 Davenport CB, Muncey EB. Huntington's chorea in relation to heredity and eugenics. Am J Insan 1916;73: 195-222.

8 Spillane J, Phillips R. Huntington's chorea in South Wales. $Q J$ Med 1937;6:403-23.

9 Panse F. Die Erbchorea: eine Klinische-genetische Studie. Samml Psychiat Neurol Einzeldarst. Leipzig: Thieme, 1942.

10 Reed TE, Chandler JH, Hughes EM, Davidson RT. Huntington's chorea in Michigan. I. Demography and genetics. Am J Hum Genet 1958:10:201-25.

11 Brothers RCD. Huntington's chorea in Victoria and Tasmania. J Neurol Sci 1964;1:405-20.

12 Cameron D, Venters GA. Some problems in Huntington's chorea. Scott Med J 1967;12:152-6.

13 Heathfield KWG. Huntington's chorea. Investigation into the prevalence of this disease in the area covered by the North East Metropolitan Board. Brain 1967;90: 203-37.
14 Oliver JE. Huntington's chorea in Northamptonshire. Br J Psychiatry 1970;166:241-53.

15 Mattsson B. Clinical, genetic and pharmacological studies in Huntington's chorea. Umea University Medical Dissertations 1974;7:21-32.

16 Stevens DL. Huntington's chorea: a demographic, genetic and clinical study. University of London: MD thesis, 1976:1-338.

17 Samuels BC, Gelfand M. Huntington's chorea in a Black Rhodesian family. $S$ Afr Med J 1978;54:648-51.

18 Glass J, Saffer DS. Huntington's chorea in a black family. $S$ Afr Med J 1979;56:685-8.

19 Brackenridge CJ. The effect of climatic temperature on the age of onset of Huntington's chorea. J Neurol Neurosurg Psychiatry 1974;37:297-301.

20 Ross R. The white population of South Africa in the eighteenth century. Population Studies 1975;29:217-30.

Requests for reprints to Dr M R Hayden, Department of Human Genetics, University of Cape Town Medical School, Observatory 7925, South Africa. 